\title{
Therapy of Type 1 Diabetes
}

\section{Abridged Version of the S3 Guideline (AWMF Register Number: 057-013; $2^{\text {nd }}$ Edition)}

\author{
Authors \\ Thomas Haak ${ }^{1}$, Stefan Gölz², Andreas Fritsche ${ }^{3}$, Martin Füchtenbusch $^{4}$, Thorsten Siegmund ${ }^{5}$, Elisabeth Schnellbächer ${ }^{6}$, \\ Harald H. Klein ${ }^{7}$, Til Uebel ${ }^{8}$, Diana Droßel ${ }^{9}$
}

\author{
Affiliations \\ 1 Diabetes Clinic, Bad Mergentheim, Germany \\ 2 Diabetic Practice, Esslingen, Germany \\ 3 Internal Medicine IV, Medical Clinic, University Hospital, \\ Tübingen, Germany \\ 4 Diabetes Center, Munich, Germany \\ 5 Isar Clinic, Munich, Germany \\ 6 Birkenfeld, Germany \\ 7 Medical University Hospital I - General Internal Medicine, \\ Endocrinology and Diabetology, Gastroenterology and \\ Hepatology, Bergmannsheil, Germany \\ 8 prima-diab Practice Dres. Uebel, Ittlingen, Germany \\ 9 Eschweiler, Germany
}

\author{
Bibliography \\ DOI https://doi.org/10.1055/a-0984-5696 \\ Exp Clin Endocrinol Diabetes 2019; 127 (Suppl 1): S27-S38 \\ (c) J. A. Barth Verlag in Georg Thieme Verlag KG Stuttgart . \\ New York \\ ISSN 0947-7349 \\ Correspondence \\ Prof. Dr. med. Thomas Haak \\ Diabetes Center Mergentheim \\ Theodor Klotzbücher-Str. 12 \\ 97980 Bad Mergentheim \\ Germany \\ haak@diabetes-zentrum.de
}

\section{Addressees and Objectives}

This guideline is directed at all people with type 1 diabetes and all occupational groups that care for people with type 1 diabetes, especially:

- Registered diabetologists,

- General practitioners and internists,

- Doctors working in hospitals (diabetes specialists, anaesthesiologists, surgeons, radiologists),

- Nurses/professional caregivers (in the operating theatre and/ or wards or in the field of diagnostics) and

- Outpatient or inpatient diabetes consultants and other professional groups in diabetology.

In addition, the guideline is directed at higher-level institutions such as health insurance companies or medical services.

In preparing and updating these guidelines, the authors pursue the following objectives:

1. Reduce the rate of diabetes-associated complications and diabetes-associated secondary damage. The diagnosis and treatment of lipodystrophy is also described for the first time;

2. Improve the quality of life of people with type 1 diabetes;
3. Contribute to the adequate care of people with type 1 diabetes in hospitals, both in regular and intensive care units. In particular, the implementation of safe protocols to protect against hypoglycaemia in intravenous insulin therapy should be supported:

4. Ensure correct treatment of acute complications and thus reduce the risk of complications due to treatment;

5. Reinforce the correct training of people with type 1 diabetes, especially in the outpatient sector.

\section{Definition and Classification of Type 1 Diabetes}

Currently, the disease diabetes mellitus is classified into 4 main types (as per etiological classification) according to the American Diabetes Association ADA [1]:

1. Type 1 diabetes (as a result of autoimmune beta-cell destruction, which usually leads to absolute insulin deficiency), Subform: idiopathic;

2. Type 2 diabetes (due to progressive loss of insulin secretion from the beta cell, often against the background of insulin resistance); 
3. Other specific diabetes types (subtypes A: genetic defects of beta cell function; B: genetic defects of insulin efficacy; C: exocrine pancreatic disease, D: diabetes due to endocrinopathies; E: drug or chemical-induced; F: diabetes resulting from infections; G: rare forms of immune-mediated diabetes; $\mathrm{H}$ : other genetic syndromes occasionally associated with diabetes);

4. Gestational diabetes (glucose tolerance disorder diagnosed for the first time in pregnancy with a $75 \mathrm{~g}$ oral glucose tolerance test).

Type 1 diabetes occurs primarily in younger years but can also manifest itself in later life. Even today, when type 1 diabetes is diagnosed, a severe metabolic derailment in the form of ketoacidosis can be seen in about 15-30\% of cases, reaching as far as loss of consciousness [2].

Within the category type 1 diabetes, 2 subtypes are currently distinguished: the immune-mediated form and the idiopathic form.

\section{Type 1 diabetes (immune-mediated, autoimmune disease)}

Type 1 diabetes is caused by a cell-mediated, chronic autoimmune destruction of beta cells. The following serological markers are suitable for diagnosing type 1 diabetes [3-8]:

- Islet cell antibodies (ICA)

- Insulin autoantibodies (IAA) (for children and adolescents but not for adults)

- Autoantibodies against glutamate decarboxylase of the B cell (GAD65A)

- Autoantibodies to tyrosine phosphatase (IA-2a) and IA-2B

- Autoantibodies against the zinc transporter 8 of the B-cell (ZnT8)

Type 1 diabetes is diagnosed when one or more of these autoantibodies are detected. At least one of these autoantibodies is detectable in $85-90 \%$ of patients with stage 3 diagnosis, i. e. simultaneous hyperglycaemia.

\section{Idiopathic type 1 diabetes}

Patients with idiopathic type 1 diabetes have a permanent insulin deficiency, tend to repeated episodes of ketoacidosis and are autoantibody negative, without etiopathogenetic classification of autoimmune type 1 diabetes. There is no association with HLA risk alleles. This form of type 1 diabetes is inherited with high penetrance, occurs very rarely and is predominantly in patients with an Asian or African background [9]. ${ }^{1}$

\section{Therapy Goals}

The therapy for type 1 diabetes aims to avoid diabetes-related reductions to the quality of life. It is also important to achieve for those affected to accept the disease and be satisfied with the therapy regime.

In order to avoid diabetes-related reductions to the quality of life, the therapy should be designed in such a way that the risk of severe metabolic disorders (severe hypoglycaemia and/or severe hyperglycaemia with ketoacidosis or diabetic coma) is as low as possible. Furthermore, the therapy should be conducted in such a way as to reduce the risk of developing microangiopathies (retinopathy, nephropathy) and other diabetes-associated secondary damage (neuropathy, accelerated macroangiopathy).

A further therapeutic goal in the treatment of type 1 diabetes is to avoid additional risk factors for consequential damage. This is done by monitoring and, if present, undergoing proper therapy for blood pressure, lipid profile and obesity-induced insulin resistance. The documentation in the Diabetes Health Pass (Gesundheitspass) can be helpful.

\begin{tabular}{|l|l|}
\hline Recommendations & $\begin{array}{l}\text { Degree of } \\
\text { recommendation }\end{array}$ \\
\hline $\begin{array}{l}\text { In adults with type } 1 \text { diabetes, an HbA1c value } \\
\text { of } 7.5 \% \text { ( } \leq 58 \text { mmol/mol) should be targeted } \\
\text { at } \leq \text { as long as no problematic hypoglycaemia } \\
\text { occurs. [10-11] }\end{array}$ & B \\
\hline $\begin{array}{l}\text { In adults with type } 1 \text { diabetes, HbA1c } \leq 6.5 \% \\
\text { ( } 48 \text { mmol/mol) may also be targeted if } \\
\text { there is a low intrinsic risk of hypoglycaemia } \\
\text { (e. g. new onset of type } 1 \text { diabetes, stable low } \\
\text { glycaemic viability). } \\
\text { [10,11] (strong consensus) }\end{array}$ \\
\hline $\begin{array}{l}\text { In adults with type } 1 \text { diabetes, a less tight } \\
\text { HbA1c value }<8.5 \% \text { (69 mmol/ mol) should } \\
\text { be sought if therapy safety cannot be } \\
\text { guaranteed, if severe hypoglycaemia has } \\
\text { frequently occurred, extensive comorbidities } \\
\text { or advanced macrovascular complications are } \\
\text { present. [10,11] (strong consensus) }\end{array}$ \\
\hline $\begin{array}{l}\text { Adults with type } 1 \text { diabetes with an HbA1c } \\
\text { value }>9 \% \text { (75 mmol/mol) or higher can be } \\
\text { assumed to have polyuria symptoms and a } \\
\text { significantly increased risk of secondary } \\
\text { diseases. Expert consensus (strong consensus) }\end{array}$ \\
\hline $\begin{array}{l}\text { In people with type } 1 \text { diabetes and severe } \\
\text { hypoglycaemia in recent months, the HbA1c } \\
\text { target should be raised. [12-14] } \\
\text { (strong consensus) }\end{array}$ \\
\hline $\begin{array}{l}\text { In people with type } 1 \text { diabetes and low life } \\
\text { expectancy or significant comorbidities, an } \\
\text { increase in blood glucose can be considered } \\
\text { with the sole therapeutic goal of symptom- } \\
\text { free treatment. [15] (strong consensus) }\end{array}$ \\
\hline
\end{tabular}

1 This classification is based on recommendations of the American Diabetic Association (ADA). 


\section{Therapy for Type 1 Diabetes}

The type 1 diabetes therapy concept consists of insulin therapy, nutritional knowledge, training, glucose self-monitoring and psychosocial care.

\section{Insulin therapy}

The indication for insulin therapy in type 1 diabetes is permanent and lifelong. A prerequisite for the substitution of lacking insulin in people with type 1 diabetes is knowledge of the physiological insulin requirement as well as the pharmacokinetic and pharmacodynamic properties of the insulins used for therapy ( $\triangleright$ Table 1 ). For the planning of insulin therapy, the following are also important: (a) consideration of how the additive insulin requirement depends on the dietary intake (prandial insulin always in addition to basal insulin requirement) and (b) the ratio between basal and prandial insulin requirement.

\section{Individual insulin needs}

In principle, the individual insulin requirement of people with type 1 diabetes resulting from an absolute insulin deficiency depends on the physiological insulin secretion. This occurs both without food intake ( = basal insulin requirement) and after food intake (= prandial insulin requirement), i.e. discontinuous and pulsatile. When dosing insulin, it must be taken into account that the absolute insulin requirement also depends on the individual insulin sensitivity of the respective patient. The therapeutic insulin requirement can therefore only be deduced preliminarily based on the insulin secretion of a healthy person.

\section{Strategies of insulin therapy}

Simple and more complex (intensified) strategies are available for insulin therapy.

\section{Conventional therapy}

Conventional therapy is characterized by a binding specification of both the insulin dose and the sequence and size of the meals (fixed carbohydrate portions). A blood glucose self-measurement is recommended 3-4 times daily. As a rule, fixed insulin mixtures are used, which are administered twice a day for breakfast and dinner and, as far as possible, adapted to the eating behaviour of the patients. A simple conventional insulin therapy can only be successful with a fixed diet plan.

In contrast to intensified therapy, this form of insulin therapy is a subordinate therapy option for people with type 1 diabetes in the following cases:

- For people who cannot meet the requirements of an intensified therapy (due to cognitive impairment, illness or age),

- For people who decide against intensified therapy after receiving extensive information on the risks and benefits,

- For people with a significant problem adhering to long-term therapies.

Since medium and long-term glycaemic control is crucial for reducing the risk of diabetes-associated complications, conventional insulin therapy can be sufficient if the individual $\mathrm{HbA} 1 \mathrm{c}$ target values are reached, hypoglycaemia is avoided, and the quality of life is not restricted by the therapy.

\section{Intensified therapy}

The intensified insulin therapy is defined as the administration of at least three insulin injections per day. Above all, however, it is characterised by substituting the basal insulin requirement with long-acting basal insulin and by substituting prandial insulin requirement with rapid-acting bolus insulin at mealtimes (basal bolus principle). Synonyms of intensified insulin therapy are functional insulin therapy and flexible insulin therapy. This therapy can be performed with insulin syringes, insulin pens or insulin pump pens (see recommendations).

\section{Insulin types}

There are currently two different groups of insulin available in Germany for insulin replacement therapy for people with type $1 \mathrm{dia}-$ betes: human insulin and insulin analogues (• Table $\mathbf{1}$ ).

The use of animal insulin can be very necessary for a few people; the possibility of importing animal insulin is hereby referred to.

\begin{tabular}{|l|l|}
\hline Recommendations & $\begin{array}{l}\text { Degree of } \\
\text { recommendation }\end{array}$ \\
\hline $\begin{array}{l}\text { Human insulins (normal insulin or human } \\
\text { insulins with delayed onset of action) or } \\
\text { insulin analogues (short-acting or } \\
\text { long-acting) are to be used for the } \\
\text { therapy of people with type 1 diabe- } \\
\text { tes.[36-43] (strong consensus) }\end{array}$ \\
\hline $\begin{array}{l}\text { If strict therapeutic goals are pursued, the } \\
\text { use of short-acting and long-acting } \\
\text { insulin analogues is associated with } \\
\text { advantages in terms of reducing HbA1c } \\
\text { and risk of hypoglycaemia as compared to } \\
\text { normal insulin. } \\
\text { [43-45] (strong consensus) }\end{array}$ \\
\hline
\end{tabular}

\section{Insulin application}

Adequate handling and correct application of the insulin used are prerequisites for successful insulin therapy. Information and review must be an integral part of the structured training. 
- Table 1 Types of insulin - efficacy, adverse effects, interactions and contraindications (with data from [16]).

\begin{tabular}{|c|c|c|c|c|c|}
\hline & \multicolumn{5}{|l|}{ Effect } \\
\hline & Onset & Maximum & Duration & Usually used & References \\
\hline \multicolumn{6}{|l|}{ Human insulins } \\
\hline $\mathrm{NPH}$ insulin & $1-2 \mathrm{~h}$ & $6-7 \mathrm{~h}$ & $14 \mathrm{~h}$ & $2 \times$ daily & {$[17-18]$} \\
\hline Normal insulin & $30-60 \mathrm{~min}$ & $3 \mathrm{~h}$ & $8 \mathrm{~h}$ & $0-30$ min before meals & {$[19]$} \\
\hline Mixed insulin NPH (70)/Normal (30) & $30-60 \mathrm{~min}$ & $3-3.5 \mathrm{~h}$ & $14 \mathrm{~h}$ & Before breakfast and dinner & {$[20-21]$} \\
\hline \multicolumn{6}{|l|}{ Insulin analogues } \\
\hline \multirow[t]{2}{*}{ Degludec } & $1-2 \mathrm{~h}^{1}$ & $8-14$ h low & $>42 \mathrm{~h}$ & $1 \times$ daily & {$[22-24]$} \\
\hline & & maximum & & & \\
\hline Detemir & $1 \mathrm{~h}$ & $7-9 \mathrm{~h}$ & $19-26 \mathrm{~h}$ & 1 or $2 \times$ daily & {$[18,25-26]$} \\
\hline Glargin U100 & $1 \mathrm{~h}$ & $8-12 \mathrm{~h}$ & $20-27 \mathrm{~h}$ & 1 or $2 \times$ daily & {$[25-27]$} \\
\hline \multirow[t]{2}{*}{ Glargin U300 } & $1-6 \mathrm{~h}^{1}$ & 12-16 h low & $30-32 \mathrm{~h}$ & $1 \times$ daily & {$[27-28]$} \\
\hline & & maximum & & & \\
\hline Aspart & $20-25 \min$ & $120-150 \mathrm{~min}$ & $4-5 \mathrm{~h}$ & $0-15$ min before meals & [29-30] \\
\hline Alulisin & $20-25 \min$ & $120-150 \mathrm{~min}$ & $4-5 \mathrm{~h}$ & $0-15$ min before meals & {$[19]$} \\
\hline Lispro & $20-25 \mathrm{~min}$ & $120-150 \mathrm{~min}$ & $4-5 \mathrm{~h}$ & $0-15$ min before meals & [31] \\
\hline Faster Aspart & $15 \mathrm{~min}$ & 120 min & $4 \mathrm{~h}$ & Immediately before meals & [29] \\
\hline Mixed insulin protamine. Aspart & $20-25 \min$ & $2-3 \mathrm{~h}$ & $10-14 \mathrm{~h}$ & $\begin{array}{l}0-15 \text { min before breakfast } \\
\text { and dinner }\end{array}$ & [30-33] \\
\hline \multicolumn{6}{|l|}{ (70)/Aspart (30); } \\
\hline \multicolumn{6}{|l|}{ protamine. Lispro (70), Lispro (30) } \\
\hline Combination insulin & $20-25 \mathrm{~min}$ & $2-3 \mathrm{~h}$ & $>30 \mathrm{~h}$ & $\begin{array}{l}0-15 \text { min before one or } \\
\text { before two main meals }\end{array}$ & [34-35] \\
\hline Degludec (70)/Aspart (30) & & & & & \\
\hline
\end{tabular}

\section{Continuous subcutaneous insulin infusion (CSII)}

\begin{tabular}{|l|l|}
\hline Recommendations & $\begin{array}{l}\text { Degree of } \\
\text { recommendation }\end{array}$ \\
\hline $\begin{array}{l}\text { In people with type } 1 \text { diabetes, the use of } \\
\text { insulin pump therapy should be examined if the } \\
\text { individual therapy goals are not achieved using } \\
\text { intensified insulin therapy. } \\
\text { [46-50] (strong consensus) }\end{array}$ & B \\
\hline $\begin{array}{l}\text { In people with type } 1 \text { diabetes, the use of } \\
\text { insulin pump therapy should be checked in } \\
\text { cases of frequent hypoglycaemia or recurrence } \\
\text { of severe hypoglycaemia using intensive insulin } \\
\text { therapy. }\end{array}$ & B \\
[49,51] (strong consensus) & \\
\hline $\begin{array}{l}\text { People with type } 1 \text { diabetes can be offered } \\
\text { insulin pump therapy in the following } \\
\text { constellations: } \\
\text { - In cases of frequently irregular daily routines, } \\
\text { e.g. shift work, activities with varying } \\
\text { physical activity, problems with the } \\
\text { implementation of classic ICT/syringe } \\
\text { therapy (among other things to improve the } \\
\text { quality of life) [52, 53], }\end{array}$ & $\mathbf{0}$ \\
\hline
\end{tabular}

\begin{tabular}{|l|l|}
\hline Recommendations & $\begin{array}{c}\text { Degree of } \\
\text { recommendation }\end{array}$ \\
\hline - In cases of planned pregnancy (begin before & \\
conception) or at the beginning of a & \\
pregnancy, & \\
- For low insulin requirements, expert & \\
consensus (EC/EK) IV, & \\
- In cases of insufficient glycaemic control of \\
the metabolic situation using ICT, e. g. dawn \\
phenomenon. \\
[54-58] (strong consensus) \\
$\begin{array}{l}\text { Prerequisites for the start of insulin pump } \\
\text { therapy in people with type 1 diabetes are: } \\
\text { - Mastery of an intensified insulin therapy on } \\
\text { the part of the patient, } \\
\text { - The provision of care by a qualified } \\
\text { diabetology staff with appropriate } \\
\text { experience in the use of insulin pumps, } \\
\text { - Insulin pump therapy training by a } \\
\text { well-trained training team. } \\
\text { Expert consensus (strong consensus) }\end{array}$ \\
\hline
\end{tabular}




\section{Blood glucose self-monitoring, rtCGM and iscCGM (FGM)}

The precision of the blood glucose self-monitoring is sufficient for self-management, even if it is lower compared to laboratory measurements $[59,60]$.

\begin{tabular}{|l|l|}
\hline Recommendations & $\begin{array}{l}\text { Degree of } \\
\text { recommendation }\end{array}$ \\
\hline $\begin{array}{l}\text { Self-management using rtCGM or iscCGM } \\
\text { (FGM) should be offered if individual therapy } \\
\text { goals are not achieved. } \\
\text { Expert consensus (strong consensus) }\end{array}$ & B \\
\hline $\begin{array}{l}\text { In order to use the advantages of a rtCGM/ } \\
\text { iscCGM system effectively, adequate training } \\
\text { and regular diabetic care by diabetic teams } \\
\text { experienced in the use of these systems are } \\
\text { required. } \\
\text { Expert consensus (strong consensus) }\end{array}$ & statement \\
\hline
\end{tabular}

\section{Nutrition}

It is of crucial importance for the therapy of type 1 diabetes that patients are able to assess the glucose efficacy of their diet in order to adjust the insulin dosage accordingly. Recommendations on the objectives, content and modalities of training for type 1 diabetes are given in section 4.4 Training/structured training and treatment programmes.

\begin{tabular}{|l|l|}
\hline Recommendations & $\begin{array}{l}\text { Degree of } \\
\text { recommendation }\end{array}$ \\
\hline $\begin{array}{l}\text { For people with type 1 diabetes, neither a } \\
\text { specific form of nutrition or diet is required, } \\
\text { nor are specific diet foods required. } \\
\text { They are subject to the general recommenda- } \\
\text { tions on healthy eating. } \\
\text { Expert consensus (strong consensus) }\end{array}$ & \\
\hline
\end{tabular}

\section{Training/structured training and treatment programmes}

In the treatment of type 1 diabetes, patients must - of their own accord - implement the essential therapeutic measures (insulin substitution usually several times a day, hypoglycaemia prophylaxis, etc.) in accordance with their individual therapy goals. The success of therapy and the prognosis of people with type 1 diabetes therefore depend very much on their ability to treat themselves [61-63]. The knowledge and skills required for this are taught in structured patient training courses. The training measures are intended to enable patients (empowerment or capacity to self-manage) “... to integrate diabetes into their own lives as best as possible on the basis of their own decisions, to avoid acute or long-term negative consequences of diabetes and to maintain their quality of life" [62].

\section{Forms of diabetes training}

\section{Basic training}

In basic training and treatment programmes, which should be carried out as soon as possible after the manifestation of diabetes or the changeover to a different therapy regime, basic knowledge and skills for the implementation of diabetes therapy, for informed decision-making and for coping with the disease are developed together with the patient. Repeated or supplementary training measures have the primary objective of supporting patients with type 1 diabetes in the event of difficulties in implementing therapy in everyday life and of offering concrete assistance with problems related to diabetes (e. g. lack of skills, problems in everyday life).

\section{Problem-specific training and treatment programmes}

These are aimed at patients in special, diabetic-specific problem situations (e.g. occurrence of secondary diseases, problems with hypoglycaemia). The indication for a problem-specific training and treatment programme may be given if the patient has to implement a specific, new form of therapy in everyday life (e. g. insulin pump therapy, continuous glucose monitoring), if significant problems are associated with acute complications (e.g. hypoglycaemia perception disorder) or in connection with subsequent complications (e. g. neuropathy, sexual disorders, diabetic foot, nephropathy, retinopathy, cardiovascular events) or when special situations exist in everyday life which make the implementation of the therapy more difficult (e.g. shift work, fasting, psychological problems) [61,64].

\section{Therapy in Special Situations}

\section{Hospital stays}

\begin{tabular}{|c|c|}
\hline Recommendations & $\begin{array}{l}\text { Degree of } \\
\text { recommendation }\end{array}$ \\
\hline $\begin{array}{l}\text { The disease type } 1 \text { diabetes should be clearly } \\
\text { indicated in the medical record during a } \\
\text { hospital stay. } \\
\text { Expert consensus per [65] (strong consensus) }\end{array}$ & $A$ \\
\hline $\begin{array}{l}\text { In all people with type } 1 \text { diabetes, an order to } \\
\text { monitor blood glucose must be issued during } \\
\text { an inpatient stay. Trained patients should be } \\
\text { able to continue self-management as far as } \\
\text { possible. The blood glucose levels should be } \\
\text { accessible to all treating members of the } \\
\text { healthcare team. If no HbA1c value from the } \\
\text { last } 3 \text { months is available, this should be } \\
\text { determined. } \\
\text { Expert consensus (strong consensus) }\end{array}$ & $A$ \\
\hline $\begin{array}{l}\text { Hospitalized patients with type } 1 \text { diabetes } \\
\text { should receive intensified insulin therapy with } \\
\text { basal insulin and bolus insulin/pump therapy. } \\
\text { Expert consensus per [11] (strong consensus) }\end{array}$ & A \\
\hline
\end{tabular}




\begin{tabular}{|l|l|}
\hline Recommendations & $\begin{array}{l}\text { Degree of } \\
\text { recommendation }\end{array}$ \\
\hline $\begin{array}{l}\text { The administration of fast-acting insulin only } \\
\text { for correction by means of a post injection plan } \\
\text { is inferior to such insulin therapy; for this } \\
\text { reason, the administration of insulin should not } \\
\text { exclusively take place in the form of a post } \\
\text { injection plan. } \\
\text { Expert consensus per [11] (strong consensus) }\end{array}$ \\
\hline
\end{tabular}

\section{Therapy during travel}

People with type 1 diabetes are not subject to significant restrictions on travel activity and destinations solely because of having diabetes. Restrictions, if any, result from secondary illnesses. It is often the case that metabolic parameters deteriorate during a journey. Consultation before travel and planning of the trip based on diabetes treatment are useful. There are many well-made recommendations available for planning purposes by self-help organisations, professional associations and also from government organisations, mostly in the form of checklists. These checklists, at least in the case of patients with type 2 diabetes requiring insulin, have also been verified within studies [66] and have found their way into most structured patient training courses.

\section{Acute Complications}

Diabetes-associated emergencies in people with type 1 diabetes are either the result of insulin deficiency or insulin overdose. Both hypo- and hyperglycaemia can be life-threatening ( $\triangleright$ Table 2 ).

\section{Hypoglycaemia}

The prevention of hypoglycaemia is one of the greatest challenges in achieving a blood glucose level as close as possible to the norm $[11,67]$.

\section{Definition/severities}

The current international classification of hypoglycaemia into mild and severe hypoglycaemia is not based on specific blood glucose values, but exclusively on the ability for self-therapy $[12,68]$ :

- Mild hypoglycaemia: Hypoglycaemia can be independently treated with carbohydrate intake by the patients.

- Severe hypoglycaemia: The patient depends on outside help in treating the hypoglycaemia (e. g. from relatives or medical personnel) (॰ Table 3).

\section{Causes and symptoms}

In people with type 1 diabetes, hypoglycaemia is always the result of an absolute or relative insulin overdose. Causes for insulin overdose can include [69]:
- Table 2 Typical symptoms of hypoglycaemia (from [67-71]).

\begin{tabular}{|l|l|l|}
\hline $\begin{array}{l}\text { Autonomic } \\
\text { symptoms }\end{array}$ & Neuroglycopenic Symptoms & $\begin{array}{l}\text { General } \\
\text { discomfort }\end{array}$ \\
\hline $\begin{array}{l}\text { Sweating } \\
\text { Trembling } \\
\text { Cravings }\end{array}$ & Mental confusion & Rapid, incoherent speech \\
Heart & Difficulty in finding words & Headache \\
palpitations & Irritability & \\
& Seeing double and other visual disorders & \\
& Headaches & \\
& Anxiety & \\
& Sleepiness & \\
& Difficulty with dexterity/coordination & \\
& Limitation of awareness and action & \\
& Unconsciousness & \\
& Cramps & \\
\end{tabular}

- Insulin dosage is too high, insulin injection at the wrong time, or the wrong type of insulin is injected

- Decreased exogenous glucose intake (forgotten meals)

- Glucose consumption is increased (e. g. after sports)

- Endogenous glucose production is lowered (for example after alcohol consumption, in case of renal insufficiency)

- Insulin sensitivity is increased (during the night, after improved glycaemic control, after improved physical fitness).

- Insulin clearance is lowered (for example, in renal insufficiency).

\section{Treatment of hypoglycaemia}

People with type 1 diabetes and hypoglycaemia perception disorder can be offered specific structured training (see section "Training/structured training and treatment programmes").

\section{Diabetic ketoacidosis}

Diabetic ketoacidosis (DKA) is a metabolic derailment due to an absolute or relative insulin deficiency and consecutive metabolization of fatty acids, which can occur with or without hyperosmolar diuresis and thus also without massive hyperglycaemia. Causes of diabetic ketoacidosis:

Diabetic ketoacidosis occurs in clinical routine during:

- Undetected first manifestation of type 1 diabetes mellitus,

- Interruption of an ongoing insulin therapy,

- Interruption of insulin administration during insulin pump therapy,

- Acute, severe diseases associated with an increased, catabolic metabolization and increased insulin requirements. 
- Table 3 Therapeutic measures in hypoglycaemic people with type 1 diabetes.

\begin{tabular}{|c|c|c|c|}
\hline Mild hypoglycaemia & \multicolumn{3}{|l|}{ Severe hypoglycaemia } \\
\hline \multirow[t]{2}{*}{ Therapy by patients possible } & \multirow{2}{*}{$\begin{array}{l}\text { Patient is conscious, } \\
\text { but therapy is no longer } \\
\text { possible by the patient. }\end{array}$} & \multicolumn{2}{|l|}{ If unconscious } \\
\hline & & Without IV access (e.g. by family/ others) & With IV access \\
\hline $\begin{array}{l}20 \mathrm{~g} \text { carbohydrates (preferably glucose; } 200 \mathrm{ml} \\
\text { fruit juice also possible) }\end{array}$ & $\begin{array}{l}30 \mathrm{~g} \text { carbohydrates } \\
\text { (glucose) }\end{array}$ & $\begin{array}{l}1 \text { mg glucagon IM or subq } \\
\text { (Warning: Vomiting and danger of aspiration) }\end{array}$ & $\begin{array}{l}50 \mathrm{ml} 40 \% \text { glucose }^{1} \\
\text { in bolus IV }\end{array}$ \\
\hline \multicolumn{2}{|c|}{$\begin{array}{l}\text { Measure blood glucose after } 15 \mathrm{~min} \text { and repeat therapy if blood glucose } \\
\text { concentration remains low }(50-60 \mathrm{mg} / \mathrm{dl} ; 2.8-3.3 \mathrm{mmol} / \mathrm{l}) \text {. } \\
\text { After successful therapy, take a meal or snack to avoid recurring hypogly- } \\
\text { caemia. }\end{array}$} & \multicolumn{2}{|c|}{$\begin{array}{l}\text { If no response is received after } 5 \text { min of therapy at the latest, repeat. } \\
\text { After successful therapy, take a meal or snack to prevent recurrent } \\
\text { hypoglycaemia. }\end{array}$} \\
\hline
\end{tabular}

\section{Biochemical definition and suspected diagnosis}

Diabetic ketoacidosis is biochemically defined by:

- Blood glucose $>250 \mathrm{mg} / \mathrm{dl}(13.9 \mathrm{mmol} / \mathrm{l})^{2}$ and

- Ketonemia and/or

- Ketonuria with arterial $\mathrm{pH}<7.35$ or

- Venous $\mathrm{pH}<7.3$; serum bicarbonate $<270 \mathrm{mg} / \mathrm{dl}$ (15 mmol/l)

The suspected diagnosis of ketoacidosis must be made if persistent hyperglycaemia $>250 \mathrm{mg} / \mathrm{dl}(13.9 \mathrm{mmol} / \mathrm{l})$ is detected in combination with ketonuria, in particular if this finding is accompanied by corresponding clinical symptoms ( $\triangleright$ Table 4 ) or a comorbidity is present. Further laboratory tests are required to confirm the diagnosis.

\section{Symptoms}

\section{Laboratory chemical diagnostics}

The following laboratory parameters are to be determined initially using quality-controlled laboratory standards if diabetic ketoacidosis is suspected: Blood glucose and ketones in urine or blood.

If these values are pathological, an arterial or venous blood gas test should be carried out and potassium levels, serum creatinine, blood count and CRP determined, as they have a decisive effect on the therapeutic regime. For outpatients, an urgent transfer to hospital must be arranged. If infections are suspected, bacterial cultures (e. g. blood, urine, pharynx) should be created.
> Table 4 Symptoms of diabetic ketoacidosis (from: $[67,72,73]$ ).

\begin{tabular}{|l|l|}
\hline $\begin{array}{l}\text { Gastrointestinal } \\
\text { Symptoms }\end{array}$ & $\begin{array}{l}\text { Loss of appetite, nausea and vomiting, } \\
\text { abdominal pain up to pseudo-peritonitis. }\end{array}$ \\
\hline $\begin{array}{l}\text { Symptoms of } \\
\text { dehydration }\end{array}$ & $\begin{array}{l}\text { Symptoms of dehydration are dry mouth, } \\
\text { standing skin folds, muscle cramps (calves, } \\
\text { abdomen), soft bulbi, drop in blood pressure, } \\
\text { polyuria (primary), oliguria (secondary). The } \\
\text { cause is osmotic diuresis due to the increased } \\
\text { blood glucose concentration (up to 100-200 g } \\
\text { glucose/day!), which leads to a significant loss of } \\
\text { fluid. This can lead to microcirculatory } \\
\text { disturbances and hyperviscosity with thrombotic } \\
\text { events. }\end{array}$ \\
\hline Respiratory & $\begin{array}{l}\text { The clinical characteristic of severe derailment is } \\
\text { metabolic acidosis, with respiratory compensa- } \\
\text { tion. To compensate an acidosis with pH values } \\
\text { of 7.1 and less, the carbon dioxide partial } \\
\text { pressure in the blood gas analysis drops down to } \\
15 \text { mmHg. The deep, laboured or slightly rapid } \\
\text { breathing is called Kussmaul's respiration. The } \\
\text { exhaled air smells of acetone, the typical, fruity } \\
\text { smell of ketoacidosis. }\end{array}$ \\
\hline Changes in & $\begin{array}{l}\text { While the state of consciousness is not restricted } \\
\text { in a mild ketoacidosis, a ketoacidosis of } \\
\text { moderate severity is associated with restrictions } \\
\text { of consciousness (drowsiness). Patients with } \\
\text { severe diabetic ketoacidosis are in a stupor or } \\
\text { comatose. }\end{array}$ \\
\hline
\end{tabular}

An extended diagnosis is to be carried out within the framework of causal research and depending on the comorbid diseases.

$(\triangleright$ Table 6)

2 The presence of diabetic ketoacidosis is defined by different international blood glucose limit values. The limit value of $250 \mathrm{mg} / \mathrm{dl}(13.9 \mathrm{mmol} / \mathrm{l})$ is based on the consensus of the author group. Since the clinical effects of high blood glucose levels can vary strongly, blood glucose levels should be assessed on the basis of the clinical picture. A single blood glucose measurement of more than $250 \mathrm{mg} / \mathrm{dl}(13.9 \mathrm{mmol} / \mathrm{l})$ without corresponding accompanying parameters is not yet a ketoacidosis. 
Severity of diabetic ketoacidosis

The classification of diabetic ketoacidosis into 3 degrees of severity follows the classification by the American Diabetes Association (ADA) [74] ( Table 5).

\begin{tabular}{|c|c|}
\hline Recommendations & $\begin{array}{l}\text { Degree of } \\
\text { recommendation }\end{array}$ \\
\hline $\begin{array}{l}\text { People with type } 1 \text { diabetes and clinical } \\
\text { suspicion of moderate or severe diabetic ketoaci- } \\
\text { dosis should be admitted to hospital immedi- } \\
\text { ately. } \\
\text { They should be treated in the clinic on the basis } \\
\text { of a detailed written treatment plan. } \\
\text { [75] (strong consensus) }\end{array}$ & $A$ \\
\hline $\begin{array}{l}\text { The monitoring of people with type } 1 \text { diabetes } \\
\text { who are being treated for diabetic ketoacidosis } \\
\text { should be carried out under intensive medical } \\
\text { conditions. } \\
\text { During the treatment of severe ketoacidosis, } \\
\text { clinical evaluation and monitoring should be } \\
\text { performed at least every hour. } \\
\text { Expert consensus as per [67] (strong } \\
\text { consensus) }\end{array}$ & A \\
\hline $\begin{array}{l}\text { Diabetic ketoacidosis should be treated } \\
\text { according to the following therapy principles: }\end{array}$ & A \\
\hline $\begin{array}{l}\text { - Circulation stabilization with initial volume of } \\
1 \text { I of isotonic solution ( } 0.9 \% \mathrm{NaCl} \text { ) in the first } \\
\text { hour; } \\
\text { Then, additional liquids and electrolytes equal } \\
\text { depending on age, height, weight and } \\
\text { possible concomitant diseases (total fluid } \\
\text { intake can be up to } 6 \mathrm{I} / 24 \mathrm{~h} \text { and more for a } \\
\text { patient weighing } 70 \mathrm{~kg} \text { ); } \\
\text { - Potassium replacement already in the } \\
\text { standard range depending on the severity of } \\
\text { the ketoacidosis by administering } 40 \mathrm{mEq} / \mathrm{L} \\
\text { potassium chloride per } 1000 \mathrm{ml} \text { NaCl } 0.9 \% \text {, } \\
\text { example see below; } \\
\text { - Slow normalization of blood glucose using } \\
\text { low-dose insulin; intravenous insulin administra- } \\
\text { tion via Perfusor (0.05-0.1 U/kg kg/h IV). } \\
\text { - Compensation of acidosis and ketosis } \\
\text { (addition of bicarbonate only at pH < } 7.0 \\
\text { and then up to a correction of } 7.1 \text { ); } \\
\text { - Avoidance of therapy complications } \\
\text { (hypokalaemia, cerebral oedema); } \\
\text { - Diagnosis and therapy of the triggering } \\
\text { causes of DKA. } \\
\text { Expert consensus as per [76] (strong } \\
\text { consensus) }\end{array}$ & \\
\hline
\end{tabular}

- Table 5 Degrees of severity of diabetic ketoacidosis.

\begin{tabular}{|l|l|l|l|}
\hline Parameter & \multicolumn{3}{|l|}{ Degree of severity } \\
\hline & Mild & Moderate & Severe \\
\hline $\mathrm{pH}$ & $<7.3$ & $\leq 7.2$ & $\leq 7.1$ \\
\hline Bicarbonate & $<270 \mathrm{mg} / \mathrm{dl}$ & $\leq 180 \mathrm{mg} / \mathrm{dl}$ & $<90 \mathrm{mg} / \mathrm{dl}$ \\
& $(15 \mathrm{mmol} / \mathrm{l})$ & $(10 \mathrm{mmol} / \mathrm{l})$ & $(5 \mathrm{mmol} / \mathrm{l})$ \\
\hline
\end{tabular}

- Table 6 Example of an infusion plan for the replacement of liquid

\begin{tabular}{|l|l|}
\hline Infusion solution & Quantity and period \\
\hline $0.9 \% \mathrm{NaCl} 1000 \mathrm{ml}$ & $1000 \mathrm{ml}$ over the next $1 \mathrm{~h}$ \\
\hline $\begin{array}{l}0.9 \% \mathrm{NaCl} 1000 \mathrm{ml} \text { with } \\
\text { potassium chloride }\end{array}$ & $1000 \mathrm{ml}$ over the next $2 \mathrm{~h}$ \\
\hline $\begin{array}{l}0.9 \% \mathrm{NaCl} 1000 \mathrm{ml} \text { with } \\
\text { potassium chloride }\end{array}$ & $1000 \mathrm{ml}$ over the next $2 \mathrm{~h}$ \\
\hline $\begin{array}{l}0.9 \% \mathrm{NaCl} 1000 \mathrm{ml} \text { with } \\
\text { potassium chloride }\end{array}$ & $1000 \mathrm{ml}$ over the next $4 \mathrm{~h}$ \\
\hline $\begin{array}{l}0.9 \% \mathrm{NaCl} 1000 \mathrm{ml} \text { with } \\
\text { potassium chloride }\end{array}$ & $1000 \mathrm{ml}$ over the next $4 \mathrm{~h}$ \\
\hline $\begin{array}{l}0.9 \% \mathrm{NaCl} 1000 \mathrm{ml} \text { with } \\
\text { potassium chloride }\end{array}$ & $1000 \mathrm{ml}$ over the next $6 \mathrm{~h}$ \\
\hline $\begin{array}{l}\text { Potassium levels in the first } \\
24 \mathrm{~h} \text { (mmol/l) }\end{array}$ & $\begin{array}{l}\text { Potassium administration per } 1000 \mathrm{ml} \\
\text { infusion solution (mEq/l) }\end{array}$ \\
\hline $\begin{array}{l}\text { Higher than } 5.5 \\
3.5-5.5 \\
<3.5\end{array}$ & $\begin{array}{l}\text { no administration } \\
40 \text { Additional oral administration of } \\
\text { potassium, if necessary }\end{array}$ \\
\hline $\begin{array}{l}\text { After } 12 \mathrm{~h} \text {, the cardiovascular situation is to be assessed and the } \\
\text { liquid replacement adjusted accordingly. }\end{array}$ \\
\hline
\end{tabular}

People with type 1 diabetes significantly underestimate the danger of ketoacidosis, as it is rather rare compared to the acute complication in the form of hypoglycaemia. Often, training on the subject of ketoacidosis took place a while ago and patients do not always remember how they can treat ketoacidosis themselves. Therefore, at regular intervals during check-ups, the topic should be addressed of recognizing ketoacidosis and treating it in a timely manner. It would be recommended to develop an evaluated short training module or other form of easily accessible information on ketoacidosis (e. g. a smartphone app). Patients should always remember that ketoacidosis is a dangerous medical situation and, in case of doubt, immediate medical assistance should be sought through the emergency medical services. 


\section{Control of diabetes-associated secondary diseases and associated risk facto}

\begin{tabular}{|c|c|}
\hline Recommendations & $\begin{array}{l}\text { Degree of } \\
\text { recommendation }\end{array}$ \\
\hline $\begin{array}{l}\text { For diagnosing lipohypertrophy, an inspection } \\
\text { of the injection sites and palpation of the skin } \\
\text { should be carried out at least once a year, and } \\
\text { quarterly in the case of abnormalities and in } \\
\text { particular in the case of inexplicably fluctuating } \\
\text { metabolic conditions. } \\
\text { Expert consensus (strong consensus) }\end{array}$ & B \\
\hline $\begin{array}{l}\text { From the age of } 11 \text { or after a diabetic duration } \\
\text { of } 5 \text { years, people with type } 1 \text { diabetes without } \\
\text { known diabetes-associated secondary diseases } \\
\text { or comorbidities should undergo the following } \\
\text { early detection examinations on a regular basis: }\end{array}$ & B \\
\hline $\begin{array}{l}\text { a. Determination of the albumin-creatinine } \\
\text { ratio and calculation of the glomerular } \\
\text { filtration rate for early detection of } \\
\text { microalbuminuria and nephropathy. } \\
\text { Expert consensus EK IV as per [77] (strong } \\
\text { consensus) } \\
\text { b. An ophthalmological retinal screening of } \\
\text { fundus in mydriasis } \\
\text { I. If no diabetic retinal changes are detected, } \\
\text { the screening interval should be two years } \\
\text { for known low risk (= no ophthalmological } \\
\text { risk and no general risk). } \\
\text { II. If the ophthalmologist does not know the } \\
\text { general risk factors, he should treat the } \\
\text { patient as if the patient had an unfavour- } \\
\text { able general risk profile; for all other risk } \\
\text { constellations, the screening interval } \\
\text { should be one year. [78] (strong } \\
\text { consensus) } \\
\text { c. Anamnesis and examination for early } \\
\text { diagnosis of neuropathy, at least annually. } \\
\text { Expert consensus as per NVL neuropathy } \\
\text { [79] (strong consensus) } \\
\text { d. Anamnesis and examination for early } \\
\text { detection of foot complications, at least } \\
\text { annually. Expert consensus as per [80] } \\
\text { (strong consensus) } \\
\text { e. Examination of the cardiovascular system, } \\
\text { risk-adapted } \\
\text { [Expert consensus as per [ } 81] \text {.] } \\
\text { In addition to a physical examination, this } \\
\text { includes the determination of biochemical } \\
\text { parameters for cardiovascular risk factors, } \\
\text { such as blood pressure measurement, } \\
\text { determination of blood lipids for the early } \\
\text { detection of lipid metabolism disorders. } \\
\text { Expert consensus (strong consensus) }\end{array}$ & \\
\hline
\end{tabular}

\section{Guideline Information}

The evidence-based guideline was prepared on behalf of the German Diabetes Society/Deutsche Diabetes Gesellschaft (DDG). President of the DDG is Prof. Dr. med. Dirk Müller-Wieland (2017-2019).

\section{Expert group appointed by the DDG Board}

- Prof. Dr. Thomas Haak, Bad Mergentheim (Coordinator)

- Dr. Stefan Gölz, Esslingen

- Prof. Dr. Andreas Fritsche, Tübingen

- PD Dr. Martin Füchtenbusch, Munich

- Dr. Thorsten Siegmund, Munich

\section{Representatives of other organisations who voted on the recommendations and commented on the content of the guideline:}

- Elisabeth Schnellbächer; Association of Diabetes Consultants and

- Training occupations in Germany/Verband der Diabetesberatungs- und Schulungsberufe Deutschlands, Birkenfeld

- Prof. Dr. Horst H. Klein, German Society for Internal Medicine/ Deutsche Gesellschaft für Innere Medizin, Bochum

- Dr. Til Uebel, German Society for General and Family Medicine/ Deutsche Gesellschaft für Allgemein- und Familienmedizin, Ittlingen

- Diana Droßel, German Diabetes Aid - People with Diabetes/ Deutsche Diabetes Hilfe - Menschen mit Diabetes, Eschweiler

German Diabetes Association: Clinical Practice Guidelines

This is a translation of the DDG clinical practice guideline published in: Diabetologie 2019; 14 (Suppl 2): S142-S152, DOI: https://doi.org/10.1055/a-0898-7429

Conflicts of Interest

An overview of the conflicts of interest can be found in the guideline report at: https://www.awmf.org/uploads/tx_szleitlinien/057-013m_ S3-Therapie-Typ-1-Diabetes_2018-04.pdf.

\section{References}

[1] American Diabetes Association 2. Classification and Diagnosis of Diabetes. Diabetes Care 2017; 40: (Suppl. 1) S11-S24. doi:10.2337| dc17-S005 LEVEL IV

[2] Johnson DD, Palumbo P], Chu CP. Diabetic ketoacidosis in a communitybased population. Mayo Clin Proc 1980; 55: 83-88. EK III

[3] Bottazzo GF, Florin-Christensen A, Doniach D. Islet-cell antibodies in diabetes mellitus with autoimmune polyendocrine deficiencies. Lancet 1974; 2: 1279-1283. EK III

[4] Palmer JP, Asplin CM, Clemons P et al. Insulin antibodies in insulindependent diabetics before insulin treatment. Science 1983; 222: 1337-1339. EK III

[5] Wiest-Ladenburger U, Hartmann R, Hartmann U et al. Combined analysis and single-step detection of GAD65 and IA2 autoantibodies in IDDM can replace the histochemical islet cell antibody test. Diabetes 1997; 46: 565-571. EK III

[6] Bingley PJ, Bonifacio E, Mueller PW. Diabetes antibody standardization program: First assay proficiency evaluation. Diabetes 2003; 52: 1128-1136. EK III 
[7] Törn C, Mueller PW, Schlosser M et al. Diabetes antibody standardization program: Evaluation of assays for autoantibodies to glutamic acid decar- boxylase and islet antigen-2. Diabetologia 2008; 51: 846-852. EK III

[8] Schlosser M, Mueller PW, Torn C et al. Diabetes Antibody Standardization Program: evaluation of assays for insulin autoantibodies. Diabetologia 2010; 53: 2611-2620. EK III

[9] Imagawa A, Hanafusa T, Miyagawa J et al. A novel subtype of type 1 diabetes mellitus characterized by a rapid onset and an absence of diabetes-related antibodies. Osaka IDDM Study Group. N Engl J Med 2000; 342: 301-307. EK III

[10] National Institute for Health and Clinical Excellence Type 1 diabetes in adults: Diagnosis and management. 2015; EK IV

[11] American Diabetes Association Standards of Medical Care in Diabetes - 2017. Diabetes Care 2017; 40: 01. level IV

[12] DCCT Research Group The effect of intensive treatment of diabetes on the development and progression of long-term complications in insulin- dependent diabetes mellitus. The Diabetes Control and Complications Trial Research Group. N Engl J Med 1993; 329: 977-986. EK Ib

[13] Fanelli CG, Epifano L, Rambotti AM et al. Meticulous prevention of hypoglycemia normalizes the glycemic thresholds and magnitude of most of neuroendocrine responses to, symptoms of, and cognitive function during hypoglycemia in intensively treated patients with short-term IDDM. Diabetes 1993; 42: 1683-1689. EK IIb

[14] Fritsche A, Stefan N, Haring $\mathrm{H}$ et al. Avoidance of hypoglycemia restores hypoglycemia awareness by increasing beta-adrenergic sensitivity in type 1 diabetes. Ann Intern Med 2001; 134: 729-736. EK IIb

[15] German Diabetes Society S2k guideline Diagnostics, therapy and follow-up of diabetes mellitus in old age. Registered guideline in development; On the Internet: http://www.awmf.org/leitlinien/detail/ registration/1/II/057-017.html. LEVEL IV

[16] Lipska KJ, Hirsch IB, Riddle MC. Human insulin for type 2 diabetes: An effective, less-expensive option. JAMA 2017; 318: 23-24. doi:10.1001/ jama.2017.6939. EK IV/LoE 4

[17] Lucidi P, Porcellati F, Marinelli Andreoli A et al. Pharmacokinetics and pharmacodynamics of nph insulin in type 1 diabetes: The importance of appropriate resuspension before subcutaneous injection. Diabetes Care 2015; 38: 2204-2210 doi:10.2337/dc15-0801. EK IV

[18] Wutte A, Plank J, Sinner F. Dose-response relationship and within-subject variability of insulin detemir and NPH insulin in subjects with type 1 diabetes. Diabetes 2004; 53: (Suppl. 2) A152. EK IV

[19] Becker RHA, Frick AD. Clinical pharmacokinetics and pharmacodynamics of insulin glulisine. Clin Pharmacokinet 2008; 47: 7-20. doi:10.2165/00003088-200847010-00002. EK III

[20] Weyer C, Heise T, Heinemann L. Insulin Aspart in a 30/70 Premixed Formulation. Pharmacodynamic properties of a rapid-acting insulin analog in stable mixture. Diabetes Care 1997; 20: 1612-1614. doi:10.2337/diacare.20.10.1612. EK III

[21] Woodworth JR, Howey DC, Bowsher RR et al. Comparative pharmacokinetics and glucodynamics of two human insulin mixtures. 70/30 and 50/50 insulin mixtures. Diabetes Care 1994; 17: 366-371. EK II

[22] Heise T, Hövelmann U, Nosek L et al. Comparison of the pharmacokinetic and pharmacodynamic profiles of insulin degludec and insulin glargine. Expert Opin Drug Metab Toxicol 2015; 11: 1193-1201. doi:1 0.1517/17425255.2015.1058779. EK III

[23] Haahr H, Heise T. A review of the pharmacological properties of insulin degludec and their clinical relevance. Clin Pharmacokinet 2014; 53 : 787-800. doi:10.1007/s40262-014-0165-y. EK I

[24] Nosek L, Coester HV, Roepstorff C et al. Glucose-lowering effect of insulin degludec is independent of subcutaneous injection region. Clin Drug In- vestig 2014; 34: 673-679. doi:10.1007/s40261-014-0218-x. EK II
[25] Koehler G, Treiber G, Wutte A et al. Pharmacodynamics of the long- acting insulin analogues detemir and glargine following single-doses and under steady-state conditions in patients with type 1 diabetes. Diabetes Obes Metab 2014; 16: 57-62. doi:10.1111/ dom.12178. EK II

[26] Heise T, Pieber TR. Towards peakless, reproducible and long-acting insulins. An assessment of the basal analogues based on isoglycaemic clamp studies. Diabetes Obes Metab 2007; 9: 648-659. doi:10.1111/j.1463-1326.2007.00756.x. EK I

[27] Becker RHA, Dahmen R, Bergmann K et al. New insulin glargine 300 Units $-\mathrm{mL}-1$ provides a more even activity profile and prolonged glyce- mic control at steady state compared with insulin glargine 100 Units • mL-1: The ELEMENT 1 study. Diabetes Care 2015; 38 : 637-643. doi:10.2337/dc14-0006. EK II

[28] Shiramoto M, Eto T, Irie S et al. Single-dose new insulin glargine $300 \mathrm{U} /$ $\mathrm{ml}$ provides prolonged, stable glycaemic control in Japanese and European people with type 1 diabetes. Diabetes Obes Metab 2015; 17: 254-260 doi:10.1111/dom.12415. EK II

[29] Heise T, Pieber TR, Danne T et al. A pooled analysis of clinical pharmacology trials investigating the pharmacokinetic and pharmacodynamic characteristics of fast-acting insulin aspart in adults with type 1 diabetes. Clin Pharmacokinet 2017; 56: 551-559. doi:10.1007/ s40262- 017-0514-8. EK II

[30] Heise T, Eckers U, Kanc K et al. The pharmacokinetic and pharmacodynamic properties of different formulations of biphasic insulin aspart: $A$ randomized, glucose clamp, crossover study. Diabetes Technol Ther 2008; 10: 479-485 doi:10.1089/dia.2008.0019. EK II

[31] Famulla S, Hovelmann U, Fischer A et al. Insulin injection into lipohypertrophic tissue: Blunted and more variable insulin absorption and action and impaired postprandial glucose control. Diabetes Care 2016; 39: 1486-1492. doi:10.2337/dc16-0610. EK II/LoE

[32] Heise T, Weyer C, Serwas A et al. Time-action profiles of novel premixed preparations of insulin lispro and NPL insulin. Diabetes Care 1998; 21: 800-803. doi:10.2337/diacare.21.5.800. EC III

[33] Rave K, Heinemann L, Puhl L et al. Premixed formulations of insulin lispro. Activity profiles in type 1 diabetic patients. Diabetes Care 1999; 22: 865-866. EK III

[34] Brunner M, Pieber T, Korsatko S et al. The distinct prandial and basal pharmacodynamics of IDegAsp observed in younger adults are preserved in elderly subjects with type 1 diabetes. Drugs Aging 2015; 32: 583-590 doi:10.1007/s40266-015-0272-y. EK II

[35] Heise T, Nosek L, Roepstorff C et al. Distinct prandial and basal glucose- lowering effects of insulin degludec/Insulin aspart (IDegAsp) at steady state in subjects with type 1 diabetes mellitus. Diabetes Ther 2014; 5: 1: 255-265. doi:10.1007/s13300-014-0070-2. EK II

[36] Institute for Quality and Efficiency in Health Care Short-acting insulin analogues for the treatment of diabetes mellitus type 1 . Final report. Order A05-02 Version 1.0; 2007 EK la

[37] Institute for Quality and Efficiency in Health Care Long-acting insulin analogues for the treatment of diabetes mellitus type 1. Final report. Order A05-01. version 1.0; 2010. EK la

[38] Singh SR, Ahmad F, Lal A et al. Efficacy and safety of insulin analogues for the management of diabetes mellitus: a meta-analysis. CMAJ 2009; 180: 385-397. EK la

[39] Monami M, Marchionni N, Mannucci E. Long-acting insulin analogues vs. NPH human insulin in type 1 diabetes. A meta-analysis. Diabetes Obes Metab 2009; 11: 372-378. EK la

[40] Mullins P, Sharplin P, Yki-Jarvinen $\mathrm{H}$ et al. Negative binomial meta-regression analysis of combined glycosylated hemoglobin and hypoglycemia outcomes across eleven Phase III and IV studies of insulin glargine compared with neutral protamine Hagedorn insulin in type 1 and type 2 diabetes mellitus. Clin Ther 2007; 29: 1607-1619. EK la 
[41] Ashwell SG, Bradley C, Stephens JW et al. Treatment satisfaction and quality of life with insulin glargine plus insulin lispro compared with $\mathrm{NPH}$ insulin plus unmodified human insulin in individuals with type 1 diabetes. Diabetes Care 2008; 31: 1112-1117. EK Ib

[42] Hermansen K, Fontaine P, Kukolja KK et al. Insulin analogues (insulin detemir and insulin aspart) versus traditional human insulins (NPH insulin and regular human insulin) in basal-bolus therapy for patients with type 1 diabetes. Diabetologia 2004; 47: 622-629. EK Ib

[43] Bühn S, Breuing J, Mathes T et al. Evidence report on selected research assignments within the $\mathrm{S} 3$ guideline "Therapy of type 1 diabetes". Witten/Herdecke: IFOM; Institute for Research in Operative Medicine (University of Witten/Herdecke); 2016

[44] Fullerton B, Siebenhofer A, Jeitler K et al. Short-acting insulin analogues versus regular human insulin for adults with type 1 diabetes mellitus. Cochrane Database Syst Rev 2016; CD012161. doi:10.1002/ 14651858.CD012161. EK la/LoE $1++$

[45] Vardi M, Jacobson E, Nini A et al. Intermediate acting versus long acting insulin for type 1 diabetes mellitus. Cochrane Database Syst Rev 2008; CD006297 EK la/LoE 1+

[46] Retnakaran R, Hochman J, DeVries JH et al. Continuous subcutaneous insulin infusion versus multiple daily injections: the impact of baseline A1c. Diabetes Care 2004; 27: 2590-2596. EK la

[47] Fatourechi MM, Kudva YC, Murad MH et al. Clinical review: Hypoglycemia with intensive insulin therapy: a systematic review and metaanalyses of randomized trials of continuous subcutaneous insulin infusion versus multiple daily injections. J Clin Endocrinol Metab 2009; 94: 729-740 EK la

[48] Jeitler K, Horvath K, Berghold A et al. Continuous subcutaneous insulin infusion versus multiple daily insulin injections in patients with diabetes mellitus: Systematic review and meta-analysis. Diabetologia 2008; 51: 941-951. EK la

[49] Pickup JC, Sutton AJ. Severe hypoglycaemia and glycaemic control in Type 1 diabetes: Meta-analysis of multiple daily insulin injections compared with continuous subcutaneous insulin infusion. Diabet Med 2008; 25: 765-774. EK IIb

[50] Bolli GB, Kerr D, Thomas R et al. Comparison of a multiple daily insulin injection regimen (basal once-daily glargine plus mealtime lispro) and continuous subcutaneous insulin infusion (lispro) in type 1 diabetes: A randomized open parallel multicenter study. Diabetes Care 2009; 32: 1170-1176. EK Ib

[51] Steineck I, Cederholm ], Eliasson B et al. Insulin pump therapy, multiple daily injections, and cardiovascular mortality in 18168 people with type 1 diabetes: Observational study. BMJ 2015; 350: h3234. EK IIb

[52] Barnard KD, Lloyd CE, Skinner TC. Systematic literature review: Quality of life associated with insulin pump use in type 1 diabetes. Diabet Med 2007; 24: 607-617. EK la

[53] Hoogma RP, Hammond P], Gomis R et al. Comparison of the effects of continuous subcutaneous insulin infusion (CSII) and NPH-based multiple daily insulin injections (MDI) on glycaemic control and quality of life: results of the 5-nations trial. Diabet Med 2006; 23: 141-147. EK Ib

[54] Mukhopadhyay A, Farrell T, Fraser RB et al. Continuous subcutaneous insulin infusion vs. intensive conventional insulin therapy in pregnant diabetic women: A systematic review and metaanalysis of randomized, controlled trials. Am J Obstet Gynecol 2007; 197: 447-456. EK la

[55] Farrar D, Tuffnell D], West ]. Continuous subcutaneous insulin infusion versus multiple daily injections of insulin for pregnant women with diabetes. Cochrane Database Syst Rev 2007; 3: CD005542. EK la

[56] Chen R, Ben-Haroush A, Weismann-Brenner A et al. Level of glycemic control and pregnancy outcome in type 1 diabetes: A comparison between multiple daily insulin injections and continuous subcutaneous insulin infusions. Am J Obstet Gynecol 2007; 197: 404-405. EK IIb
[57] Cypryk K, Kosinski M, Kaminska P et al. Diabetes control and pregnancy outcomes in women with type 1 diabetes treated during pregnancy with continuous subcutaneous insulin infusion or multiple daily insulin injections. Pol Arch Med Wewn 2008; 118: 339-344. EK IIb

[58] Gimenez M, Conget I, Nicolau J et al. Outcome of pregnancy in women with type 1 diabetes intensively treated with continuous subcutaneous insulin infusion or conventional therapy. A case-control study. Acta Diabetol 2007; 44: 34-37. EK III

[59] Alto WA, Meyer D, Schneid J et al. Assuring the accuracy of home glucose monitoring. I Am Board Fam Pract 2002; 15: 1-6. EK III

[60] Saudek CD, Derr RL, Kalyani RR. Assessing glycemia in diabetes using self-monitoring blood glucose and hemoglobin A1c. JAMA 2006; 295 : 1688-1697. EK IV

[61] German Medical Association, National Association of Statutory Health Insurance Physicians, Association of Scientific Medical Societies National Care Guideline Diabetes - Structured Training Programs Long Version. 1st Edition. Version 4: On the Internet: http://www. dm-schulung.versorgungsleitlinien.de; Version: 04.11.2017. EK IV

[62] Kulzer B, Albus C, Herpertz S et al. Psychosocial and diabetes (Part 1). Diabetology and metabolism 2013; a 8: 198-242. doi:10.1055/ s-0033-1335785. level IV

[63] Kulzer B, Albus C, Herpertz S et al. Psychosocial and diabetes (Part 2). Diabetology and metabolism 2013; b 8: 292-324. doi:10.1055/ s-0033-1335889. level IV

[64] Hermanns N, Kulzer B, Krichbaum M. Problem-specific patient training. Overview of an essential component of diabetes therapy. Diabetologist 2008; 4: 361-367 th level III

[65] American Diabetes Association 14. Diabetes Care in the Hospital. Diabe- tes Care 2017; 40: (Suppl. 1) S120-S127. doi:10.2337| dc17-S017. EK IV

[66] Chen HS, Wu TE, Jap TS et al. Effects of health education on glycemic control during holiday time in patients with type 2 diabetes mellitus. Am J Manag Care 2008; 14: 45-51 st EK Ib/LoE

[67] Canadian Diabetes Association 2013 Clinical Practice Guidelines for the Prevention and Management of Diabetes in Canada. Im Internet: http://guidelines.diabetes.ca/app_themes/cdacpg/resources/ cpg_2013_full_en.pdf; Stand: 23.07.2017. EK IV

[68] Graveling AJ, Frier BM. Hypoglycaemia: An overview. Prim Care Diabetes 2009; 3: 131-139 th level III

[69] Cryer PE. The barrier of hypoglycemia in diabetes. Diabetes 2008; 57 : 3169-3176. EK III

[70] Deary I], Hepburn DA, MacLeod KM et al. Partitioning the symptoms of hypoglycaemia using multi-sample confirmatory factor analysis. Diabetologia 1993; 36. 771-777. EK III/LoE 3

[71] McAulay V, Deary IJ, Frier BM. Symptoms of hypoglycaemia in people with diabetes. Diabet Med 2001; 18: 690-705. EK III

[72] Haak T, Kellerer M.German Diabetes Society Diagnostics, therapy and follow-up of diabetes mellitus in children and adolescents.Mainz; Kirchheim: 2009 EK IV

[73] Kitabchi AE, Umpierrez GE, Murphy MB et al. Hyperglycemic crises in adult patients with diabetes: a consensus statement from the American Diabetes Association. Diabetes Care 2006; 29: 2739-2748 EK IV

[74] Kitabchi AE, Umpierrez GE, Miles JM et al. Hyperglycemic crises in adult patients with diabetes. Diabetes Care 2009; 32: 1335-1343. EK IV

[75] Bull SV, Douglas IS, Foster M et al. Mandatory protocol for treating adult patients with diabetic ketoacidosis decreases intensive care unit and hospital lengths of stay: Results of a nonrandomized trial. Crit Care Med 2007; 35: 41-46 EK IIb 
[76] Joint British Diabetes Societies for inpatient care The Management of Diabetic Ketoacidosis in Adults. Second Edition Update: September. 2013; Im Internet: http://www.diabetologists-abcd.org.uk/JBDS/ JBDS_IP_DKA_Adults_Revised.pdf; Stand: 23.09.2017. EK IV

[77] German Medical Association, National Association of Statutory Health Insurance Physicians, Association of Scientific Medical Societies National Care Guideline Type 2 Diabetes - Kidney Diseases in Adult Diabetes. Version Consultation 1.0; 2010. level IV

[78] German Medical Association, National Association of Statutory Health Insurance Physicians, Association of Scientific Medical Societies National guideline for the prevention and treatment of retinal complications associated with diabetes - Long version. 2nd edition. Version 2: On the Internet: http://www.netzhautkomplikationen. versorgungsleitlinien.de Status: 19.10.2017. EK IV
[79] German Medical Association, National Association of Statutory Health Insurance Physicians, Association of Scientific Medical Societies National care guideline Neuropathy in diabetes in adolescence. 2010; LEVEL IV

[80] German Medical Association, National Association of Statutory Health Insurance Physicians, Association of Scientific Medical Societies National Care Guideline Type 2 Diabetes - Prevention and Treatment Strategies for Fußkomplikationen. Version. 2.8; 2006 EK IV

[81] German Medical Association, Association of Scientific Medical Societies, National Association of Statutory Health Insurance Physicians National guideline for kidney disease in adult diabetes. 2010; LEVEL IV 